\title{
TINGKAT PENGETAHUAN IBU HAMIL TRIMESTER III TENTANG PERDARAHAN PERSALINAN KALA IV DI KLINIK ROMANA TAHUN 2021
}

\author{
Aprilita Br Sitepu ${ }^{1}$, Treymei Sitorus ${ }^{2}$ \\ ${ }^{1,2}$ STIKes Santa Elisabeth Medan, Indonesia

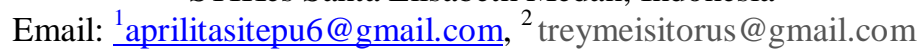

\begin{abstract}
Abstrak
Perdarahan persalinan kala IV ialah perdarahan yang jumlahnya $\pm 500 \mathrm{ml}$ yang dimana terjadi setelah bayi lahir pervaginam sampai 2 jam. Tujuan penelitian ini untuk mengidentifikasi Tingkat Pengetahuan Ibu Hamil Trimester III Tentang Perdarahan Persalinan Kala IV berdasarkan umur, paritas, pendidikan, pekerjaan. Penilitian ini bersifat deskriptf dengan populasi 30 dan sampel 20 Ibu Hamil Trimester III. Pengukuran tingkat pengetahuan menggunakan kuesioner dengan dengan teknik Accidental Sampling. Analisis data Univariat dengan menghitung presentase. Didapatkan dari hasil penelitian bahwa Tingkat Pengetahuan Ibu Hamil Trimester III paling banyak dalam kategori cukup yaitu 10 orang (50\%), sedangkan paling sedikit berpengetahuan kurang yaitu 3 orang (15\%). Berdasarkan umur sebagian besar responden berpengetahuan cukup berumur 20-35 tahun sebanyak 18 orang (90\%) dan sebagian kecil responden berumur $<20$ dan $>35$ tahun yaitu masing-masing 1 orang $(5 \%)$. Berdasarkan paritas mayoritas responden berpengetahuan cukup yaitu multipara 11 orang $(55 \%)$ dan minoritas berpengetahuan cukup yaitu primipara 4 orang $(20 \%)$. Berdasarkan pendidikan mayoritas responden berpengetahuan cukup adalah SMA yaitu 12 orang (60\%), dan minoritas responden berpengetahuan cukup adalah Diploma dan Sarjana yaitu masing-masing 4 orang (20\%). Berdasarkan pekerjaan mayoritas responden berpengetahuan cukup adalah tidak bekerja yaitu 11 orang $(55 \%)$, dan minoritas responden berpengetahuan cukup adalah yang bekerja yaitu 9 orang $(45 \%)$.
\end{abstract}

Kata kunci: Pengetahuan, Ibu Hamil Trimester III, Perdarahan Persalinan Kala I

\begin{abstract}
Bleeding in the fourth stage of labor is bleeding in the amount of $\pm 500 \mathrm{ml}$ which occurs after the baby is born vaginally for up to 2 hours. The purpose of this study was to identifity the level of knowledge of third trimester pregnant women about childbirth bleeding in the fourth stage based on age, parity, education, and occupation. This research is descriptive with a population of 30 and a sample of 20 pregnant women in the third trimester. Measurement of the level of knowledge using a questionnaire with Accidental Sampling technique. Univariate data analysis by calculating the percentage. Result : It was found from the results of the study that the level of knowledge of pregnant women in the third trimester was mostly in the sufficient category, namely 10 people (50\%), while the least knowledge was 3 people (15\%). Based on age, most of the respondents with sufficient knowledge were aged 20-35 years as many as 18 people (90\%) and a small proportion of respondents aged $<20$ and >35 years, namely 1 person (5\%). Based on parity, the majority of respondents had sufficient knowledge, namely 11 people (55\%) multipara and 4 people (20\%). Based on education, the majority of respondents who have sufficient knowledge are SMA with 12 people (60\%), and the minority of respondents with sufficient knowledge are Diplomas and Bachelors, which are 4 people (20\%). Based on occupation, The majority of respondents with sufficient knowledge are unemployed, namely 11 people (55\%), and the minority of respondents with sufficient knowledge are those who work, namely 9 people (45\%).
\end{abstract}

Keywords: Knowledge, Third Trimester Pregnant Women, Childbirth Bleeding Stage IV 


\section{Pendahuluan}

Perdarahan persalinan kala IV yang jumlahnya lebih dari $500 \mathrm{ml}$ yang terjadi setelah bayi lahir pervaginam sampai 2 jam. Dimana kondisi persalinan ini menjadi penyebab sulitnya dalam menentukan jumlah perdarahan yang terjadi jika dilihat dari jumlah perdarahan, maka bias disebutkan sebagai perdarahan yang melebihi dari batas normal atau perdarahan yang lebih dari biasanya, yang akan mempengaruhi pada perubahan tanda-tanda vital (Tekanan Darah $<90 / 60 \mathrm{mmHg}$, Nadi >100 x/menit), kesadaran melemah, menggigil keringat dingin, dan kadar $\mathrm{Hb}<8 \mathrm{~g} / \mathrm{dL}$. (Sulis Diana, dkk 2019)

Yang paling dikenal sebagai penyebab utama kematian ibu disamping infeksi dan preEklampsia adalah perdarahan pada pascapersalinan. Perdarahan pascapersalinan adalah perdarahan yang bias dikatakan sering terjadi yang dimana bersal dari tempat implantasinya plasenta bisa juga robekan jalan lahir, merupakan perdarahan yang sering terjadi yang berasal dari tempat implantasi plasenta, robekan jalan lahir, dan menjadi salah satu penyebab dari kematian ibu disamping perdarahan karena abortus maupun kehamilan ektopik terganggu. (Sarwono, 2016)

Menurut data $W H O$, angka kematian ibu didunia pada tahun 2017 adalah 216 per 105.000 KH atau bisa diperkirakan jumlah kematian ibu adalah 303.000 kematian dengan jumlah tertinggi berada di Negara berkembang yaitu sebesar 302.000 kematian. (Kemenkes RI, 2017)

Tingginya kasus kesakitan dan kematian ibu dibanyak Negara berkembang termasuk Indonesia, salah satunya disebabkan oleh perdarahan pascapersalinan (22\%). Dengan program kesehatan dan teknologi kedokteran saal ini, sebagian besar penyebab utama kesakitan kematian ibu tersebut sebenarnya dapat ditanggulangi dan kematian ibu dapat dicegah. Negara Asia dengan pemasukan devisa yang terbatas seperti Srilanka, ternyata dapat menurunkan menurunkan Angka Kematian Ibu (AKI) secara bermakna melalui strategi yang sederhana yaitu semua persalinan harus dilakukan di Fasilitas kesehatan dan didorong oleh petugas kesehatan yang terampil. (JNPK-KR, 2017)

Jumlah Kematian Ibu di Kota Medan (2018) sebanyak 5 jiwa dari 37.918 kelahiran hidup, dengan Angka AKI dilaporkan sebesar 13 per 100.000 kelahiran hidup, artinya dari 100.000 Kelahiran Hidup $13 \mathrm{ibu}$ meninggal saat kehamilan, persalinan dan nifas. Jika dibandingkan dengan dengan tahun sebelumnya, AKI di kota Medan mengalami kenaikan yang sangat drastis. Yang dimana pada tahun 2017 didapatkan jumlah kematian ibu terdapat 3 jiwa dari 47.541 kelahiran hidup, pada tahun 2016 jumlah kematian ibu sebanyak 3 jiwa dari 39.594 kelahiran hidup. (Kemenkes, 2018)

Berdasarkan Profil Kesehatan Kota Medan tahun 2018, faktor penyebab kematian ibu antara lain disebebkan oleh perdarahan pada saat persalinan dan akibat dari komplikasi kehamilan. (Kemenkes, 2018)

Berdasarkan penelitian Dewanti Sanjaya Putri tahun 2018, didapatkan kasus yang paling sering ditemui di Kabupaten Bantul adalah kasus perdarahan, yang dimana di Puskesmas 
Sedayu I terdapat 8 kasus ibu yang mengalami perdarahan pada saat persalinan. Dimana data yang didapatkan, hasil Audit Maternal Perinatal (AMP) menunjukkan bahwa penyebab kematian ibu adalah perdarahan, infeksi, dan pre-Eklampsia berat.

Berdasarkan penelitian Dewi Yulia Sari, didapatkan bahwa faktor dari penyebab tingginya Angka Kematian Ibu adalah perdarahan (30,3\%), terutama perdarahan pascapersalinan.

Berdasarkan penelitian yang didapat E Kaban yang dilakukan di RSUD Kabanjahe tahun 2018 adalah dengan kategori perdarahan persalinan kala IV yaitu plasenta rest, atonia uteri, laserasi jalan lahir, dan retensio plasenta. Yang dimana terjadi peningkatan prevalensi pada ibu yang bersalin dimana ibu yang mengalami perdarahan pascapersalinan tahun 2017 sebanyak 34 kasus (31\%) dan pada tahun 2018 sebanyak 51 kasus (36\%).

Berdasarkan survei pendahuluan yang saya lakukan selama praktek klinik kebidanan di Klinik Romana pada tanggal 16 - 30 November 2020, bahwa jumlah keseluruhan Ibu Hamil trimester III ada 10 orang. Ibu hamil yang mengetahui Perdarahan Persalinan Kala IV berjumlah 4 orang, sedangkan 6 lagi tidak mengetahui apa itu Perdarahan Persalinan Kala IV. Dan ditemukan seluruh ibu bersalin hanya 5 orang, akan tetapi jumlah dari 5 orang diantaranya 3 mengalami perdarahan persalinan dikala IV.

Berdasarkan latar belakang diatas dan masalah yang ada maka penulis tertarik untuk mengambil judul "Tingkat Pengetahuan Ibu Hamil Trimester III Tentang Perdarahan Persalinan Kala IV”.

\section{Metode Penelitian}

Desain penelitian yang digunakan adalah Deskriptif, yang dilakukan dengan tujuan untuk mengetahui sejauh mana Tingkat Pengetahuan Ibu Hamil Trimester III tentang Perdarahan Persalinan Kala IV di Klinik Romana Medan Tahun 2021. Populasi dari penelitian ini adalah Ibu Hamil Trimester III di Klinik Romana sebanyak 30 orang.

Teknik Pengambil sampel dalam penelitian ini adalah Accidental Sampling yaitu sebanyak 20 orang Ibu Hamil Trimester III. Dengan kriteria sampel adalah dapat berkomunikasi dengan baik, dapat membaca, dapat menulis dan dapat bersedia menjadi responden.

\section{Hasil dan Pembahasan}

Setelah melakukan penelitian selama 1 bulan mengenai Tingkat Pengetahuan Ibu Hamil Trimester III tentang Perdarahan Persalinan Kala IV di Klinik Romana tahun 2021, maka di peroleh sampel sebanyak 20 orang. Berdasarkan hal tersebut maka di jabarkan di bawah ini :

Tabel. 1 Distribusi Frekuensi Tingkat Pengetahuan Ibu Hamil Trimester III tentang Tentang Perdarahan Persalinan Kala IV di Klinik Romana 2021:

\begin{tabular}{llll}
\hline No & Pengetahuan & Frekuensi & Presentase \\
\hline $\mathbf{1}$ & Baik & 7 & 35 \\
2 & Cukup & 10 & 50 \\
3 & Kurang & 3 & 15
\end{tabular}




\begin{tabular}{lcc}
\hline Total & 24 & 100 \\
\hline
\end{tabular}

Dapat dilihat dari tabel 1 menunjukan bahwa Tingkat Pengetahuan Ibu Hamil Trimester III tentang perdarahan persalinan kala IV paling banyak dalam kategori berpengetahuan cukup yaitu 10 orang (50\%), sedangkan paling sedikit berpengetahuan kurang yaitu 3 orang (15\%).

Tabel. 2 Distribusi Frekuensi Tingkat Pengetahuan Ibu Hamil Trimester III tentang Perdarahan Persalinan Kala IV Berdasarkan Umur di Klinik Romana 2021

\begin{tabular}{lllc}
\hline No & Umur & Frekuensi & Presentase \\
\hline 1 & $<20$ tahun & 1 & 5 \\
2 & $20-35$ tahun & 18 & 90 \\
3 & $>35$ tahun & 1 & 5 \\
\hline & Total & $\mathbf{2 0}$ & $\mathbf{1 0 0}$ \\
\hline
\end{tabular}

Dapat dilihat dari tabel 2 diatas menunjukkan bahwa sebagian besar responden berpengetahuan cukup berumur 20-35 tahun sebanyak 18 orang (90\%) dan sebagian kecil responden berumur $<20$ tahun dan $>35$ tahun yaitu masing-masing 1 orang $(5 \%)$.

Tabel 3 Distribusi Frekuensi Tingkat Pengetahuan Ibu Hamil Trimester III Tentang Perdarahan Persalinan Kala IV Berdasarkan Paritas di Klinik Romana 2021

\begin{tabular}{llcc}
\hline No & Paritas & Frekuensi & Presentase \\
\hline 1 & Nullipara & 5 & 25 \\
2 & Primipara & 4 & 20 \\
3 & Multipara & 11 & 55 \\
\hline & Total & $\mathbf{2 0}$ & $\mathbf{1 0 0}$ \\
\hline
\end{tabular}

Dari tabel 3 diatas menunjukkan bahwa mayoritas responden berpengetahuan cukup yaitu multipara 11 orang (55\%) dan minoritas berpengetahuan cukup yaitu primipara 4 orang $(20 \%)$.

Tabel 4 Distribusi Frekuensi Tingkat Pengetahuan Ibu Hamil Trimester III tentang Perdarahan Persalinan Kala IV Berdasarkan Pendidikan di Klinik Romana 2021

\begin{tabular}{llll}
\hline No & Pendidikan & Frekuensi & Presentase \\
\hline 1 & SMA & 12 & 60 \\
2 & Diploma & 4 & 20 \\
3 & Sarjana & 4 & 20 \\
\hline & Total & $\mathbf{2 0}$ & $\mathbf{1 0 0}$ \\
\hline
\end{tabular}


Dari tabel 4 diatas menunjukkan bahwa mayoritas pendidikan responden berpengetahuan cukup adalah SMA yaitu 12 orang (60\%), dan minoritas responden berpengetahuan cukup adalah Diploma dan Sarjana yaitu masing-masing 4 orang (20\%).

Tabel 5 Distribusi Frekuensi Tingkat Pengetahuan Ibu Hamil Trimester III tentang Perdarahan Persalinan Kala IV Berdasarkan Pekerjaan di Klinik Romana 2021

\begin{tabular}{lllc}
\hline No & Pekerjaan & Frekuensi & Presentase \\
\hline 1 & Bekerja & 9 & 45 \\
2 & Tidak Bekerja & 11 & 55 \\
\hline & Total & $\mathbf{2 0}$ & $\mathbf{1 0 0}$ \\
\hline
\end{tabular}

Dari tabel 5 diatas menunjukkan bahwa mayoritas responden berpengetahuan cukup adalah tidak bekerja yaitu 11 orang (55\%), dan minoritas responden berpengetahuan cukup adalah yang bekerja yaitu 9 orang $(45 \%)$.

\section{Tingkat Pengetahuan Ibu Hamil Trimester III tentang Perdarahan Persalinan Kala IV}

Menurut data hasil penelitian Rumini (2019), dengan hasil penelitian menunjukan bahwa pengetahuan Ibu Hamil Trimester III tentang persalinan yang aman di Puskesmas Kaligesing dalam kategori cukup. Berdasarkan hal tersebut peneliti mengasumsikan bahwa tinggi ataupun rendahnya pengetahuan seseorang dipengaruhi oleh berbagai macam faktor, diantaranya umur, tingkat pendidikan, pekerjaan serta pengalaman (jumlah anak yang dilahirkan).

Berdasarkan asumsi penelitian Dewanti (2018), Ibu hamil yang berpengetahuan baik persentasinya lebih rendah dari Ibu hamil yang berpengetahuan cukup ditambah ibu yang berpengetahuan kurang, hal ini dapat disebabkan karena rendahnya pendidikan yang dimiliki oleh sebagian ibu hamil sehingga kurangnya pengetahuan, menurut teori dari Notoatmodjo (2017), mengemukakan bahwa seseorang dengan tingkat pengetahuan yang lebih baik memiliki pemahaman yang lebih baik tentang perdarahan, Pengetahuan yang membuat ibu hamil lebih mengerti upaya-upaya dan tindakan-tindakan yang perlu dilakukan dalam penanganan perdarahan pada saat persalinan.

Menurut asumsi peneliti, bahwa penegtahuan Ibu Hamil Trimester III paling banyak berpengetahuan cukup sebanyak 10 orang atau sebesar (50\%), hal ini disebabkan kurangnya pengetahuan Ibu Hamil Trimester III yang disebabkan oleh beberapa factor diantaranya umur, paritas, pendidikan, pengalaman dan lain sebagainya. Penelitian ini sesuai dengan teori menurut Notoatmodjo (2012) Yang dimana beberapa faktor yang mempengaruhi pengetahuan diantaranya yaitu faktor pendidikan, dimana semakin tinggi pendidikan semakin cepat menerima dan memahami suatu informasi sehingga pengetahuan yang dimiliki juga semakin tinggi.

Tingkat Pengetahuan Ibu Hamil Trimester III Tentang Perdarahan Persalinan Kala IV Berdasarkan Umur. 
Berdasarkan hasil penelitian, menunjukkan bahwa sebagian besar responden berpengetahuan cukup berumur 20-35 tahun sebanyak 18 orang $(90 \%)$ dan sebagian kecil responden berumur $<20$ tahun dan $>35$ tahun yaitu masing-masing 1 orang $(5 \%)$.

Umur seseorang dapat memenuhi tingkat pengetahuan seseorang karena pola pikir yang mengalami perubahan secara terus menerus sepanjang hidupnya. Yang dimana semakin bertambah usia akan semakin berkembang pula data tangkap dan pola pikir seseorang dan akan menurun dimana sejalan bertambahnya usia. (Riyanto, 2016)

Berdasarkan asumsi penelitian yang telah dilakukan Rumini (2019), dimana didapatkan pengetahuan ibu umur 20-35 tahun cenderung lebih baik jika dibandingkan dengan kelompok ibu yang lain, yang dimana peneliti mengasumsikan bahwa ibu dengan umur 20-35 tahun lebih cepat dan mudah menerima informasi dari pergaulannya dengan orang lain dan lingkungannya.

Menurut asumsi peneliti, bahwa pengetahuan responden sebagian besar responden berpengetahuan cukup berumur 20-35 tahun sebanyak 18 orang (90\%), hal ini menunjukkan bahwa kurangnya pengetahuan ibu hamil pada umur 20-35. Semakin bertambahnya usia maka akan semakin berkembang pula daya tangkap dan pola pikirnya sehingga pengetahuan yang diperoleh juga akan semakin membaik dan bertambah. Hal ini sejajar dengan penelitian Istiarti, yang dimana menyatakan bahwa faktor yang mempengaruhi pengetahuan diantaranya adalah paparan media massa, pendidikan dan pengalamannya.

\section{Tingkat Pengetahuan Ibu Hamil Trimester III Tentang Perdarahan Persalinan Kala IV Berdasarkan Paritas.}

Berdasarkan hasil penelitian, menunjukan bahwa mayoritas responden berpengetahuan cukup yaitu multipara 11 orang (55\%) dan mioritas berpengetahuan cukup yaitu primipara 4 orang $(20 \%)$.

Paritas adalah jumlah anak yang hidup saat ini dan yang telah dilahirkan sampai persalinan terakhir. Jumlah paritas yang bias dikatakan aman adalah 2-3 anak, dan apabila terlalu banyak melahirkan lebih dari 4 kali akan menyebabkan beberapa faktor salah satunya seperti perdarahan persalinan. (Meita, 2016)

Berdasarkan asumsi dari hasil penelitian yang sudah dilakukan Rumini (2019), diperoleh ibu hamil dengan jumlah anak yang dilahirkan 3 mempunyai pengetahuan yang cukup. Peneliti mengasumsikan bahwa seseorang yang sudah pernah melahirkan akan mempunyai pengalaman yang lebih bila dibandingkan dengan seseorang yang belum pernah memiliki pengalaman melahirkan.

Menurut asumsi peneliti, responden memiliki pengetahuan yang cukup tentang Perdarahan Persalinan Kala IV mayoritas ibu hamil dengan paritas multipara 11 orang $(55 \%)$, yang dimana peneliti mengasumsikan bahwa tingkat pengetahuan Ibu Hamil Trimester III akan lebih matang atau lebih mengetahui tentang perdarahan persalinan kala IV jika memiliki pengalaman melahirkan. Peneliti mengasumsikan bahwa semakin banyak paritas maka pengetahuannya akan semakin tinggi, hal ini ada kaitannya dengan pengaruh pengalaman sendiri maupun orang lain, sama halnya dengan seorang ibu yang telah mempunyai paritas, dia akan mempunyai pengalaman sebelumnya jika dibandingkan dengan dia yang belum mempunyai paritas. Yang dimana semakin banyak pengalaman seseorang mendapatkan pengetahuan maka adakn semakin banyak yang telah dipahami. 


\section{Tingkat Pengetahuan Ibu Hamil Trimester III tentang Perdarahan Persalinan Kala IV Berdasarkan Pendidikan.}

Berdasarkan hasil penelitian, menunjukan bahwa mayoritas pendidikan responden berpengetahuan cukup adalah SMA yaitu 12 orang (60\%), dann minoritas responden berpengetahuan cukup adalah Diploma dan Sarjana yaitu masing-masing 4 orang (20\%).

Pendidikan adalah suatu usaha untuk mengembangkan kepribadian dan kemampuan seseorang yang berlangsung seumur hidup. Semakin tinggi pendidikann seseorang semakin banyak pula informasi yang masuk, dan pengetahuan yang didapat tentang kesehatan. (Fitriani 2015)

Berdasarkan hasil dari penelitain yang telah dilakukan Rumini (2019), dapat diketahui bahwa tingkat pendidikan PT memiliki pengetahuan yang baik. Hal ini sesuai dengan pendapat yang dikemukakan Notoatmojo (2012), bahwa pendidikan mempengaruhi pengetahuan seseorang yang mempunyai pendidikan lebih tinggi akan lebih mudah menerima informasi yang disampaikan, latar belakang pendidikan yang rendah akan sulit menangkap informasi tentang pengetahuan.

Jika dibandingkan dengan teori yang ada, pada penelitian ini terdapat suatu kesenjangan antara teori dengan hasil penelitian, menurut teori (Wawan \& M, 2019) dan Notoatmodjo (2017) pengetahuan seseorang dipengaruhi oleh pendidikan seseorang maka semakin baik pengetahuan dan lebih luas dibandingkan pendidikan yang lebih rendah. Hal ini dapat terjadi karena tidak semua orang yang berpendidikan tinggi pengetahuannya pun tinggi, pencarian ilmu pengetahuan antara yang berpendidikan dan tidak berpendidikan itu sama, tergantung diri seseorang untuk mendapatkan pengetahuan tersebut.

Menurut asumsi peneliti, responden memiliki pengetahuan yang cukup tentang Perdarahan Persalinan Kala IV mayoritas ibu hamil berpendidikan SMA (60\%), dimana pendidikan sangatlah mempengaruhi tingkat pengetahuam seseorang. Akan tetapi, perlu diketahui bahwa untuk mengukur pengetahuan seseorang hanya dapat diukur dari segi umur, paritas dan pendidikan saja masih ada faktor yang lainnya beserta jumlah responden yang diperoleh karena pengetahuan bisa didapatkan melalui pancaindera yang dimana dapat diartikan bahwa pengetahuan tidak selalu didapatkan melalui pendidikan, bisa juga melalui internet, surat kabar, buku, dan berita bahkan bisa juga didapat melalui percakapan dengan orang lain yang dapat mengetahui tentang suatu hal.

\section{Tingkat Pengetahuan ibu Hamil trimester III Tentang Perdarahan Persalinan Kala IV Berdasarkan Pekerjaan.}

Berdasarkan hasil penelitian, menunjukan bahwa mayoritas respponden berpengetahuan cukup adalah tidak bekerja yaitu 11 orang $(55 \%)$, dan minoritas responden berpengetahuan cukup adalah yang bekerja yaitu 9 orang (45\%).

Pekerjaan merupakan cara mencari nafkah yang mempunyai tantangan. Pada umumnya bekerja merupakan kegiatan yang menyita banyak waktu. (Wawan \& $\mathrm{M}$, 2019) 
Berdasarkan hasil penelitian yang telah dilakukan Rumini (2019), dapat diketahui bahwa pendidikan responden mayoritas adalah yang tidak bekerja, atau bisa juga disebut sebagai ibu rumah tangga mempunyai pengetahuan cukup sebanyak 9 orang. Penjelasan tersebut sesuai dengan teori bahwa seseorang mempunyai sumber informasi yang baik akan mempunyai pengetahuan yang lebih luas (Soekanto, 2014). Sedangkan pada kelompok ibu rumah tangga yang tingkat pengetahuannya cukup dikarenakan lebih sering mengurus rumah.

Berdasarkan penelitian yang dilakukan oleh Dewanti menunjukan ibu hamil yang bekerja memiliki pengetahuan baik namun persentasinya lebih rendah dari ibu hamil yang tidak bekerja karena ibu hamil yang tidak bekerja pada umumnya mempunyai banyak waktu luang untuk mengakses informasi baik dari tenaga kesehatan maupun dari media cetak dan elektrolit dibandingkan dengan ibu yang bekerja.

Menurut asumsi peneliti, bahwa pengetahuan responden berdasarkan pekerjaan yang tidak bekerja mayoritas berpengetahuan cukup sebanyak 7 orang sebesar (54,5\%), hal ini menunjukkan bahwa ibu hamil trimester III dengan pekerjaan yang tidak bekerja sedikit mengetahui tentang perdarahan persalinan kala IV. Hal ini menunjukkan bahwa proporsi terbesar adalah ibu rumah tangga atau ibu yang tidak bekerja. Karena ibu rumah tangga diasumsikan dalam berpengaruh pada proses komunikasi, memberi nasehat bimbingan, arahan, dan pengawasan ibu terhadap anak, dan ibu rumah tangga mudah mendapatkan informasi dan sumber pengetahuan up to date kapanpun dan dimana pun jika dibandingkan dengan ibu yang bekerja lebih sedikit mempunyai waktu untuk anaknya sehingga anak kurang dalam mendapatkan pengetahuan atau informasi dan dukungan karena ibu sedang bekerja (Mediana, 2014).

\section{Kesimpulan}

Dari hasil penelitian yang telah dilakukuan terhadap ibu hamil trimester III tentang Pendarahan Persalinan Kala IV di Klinik Romana Tahun 2021 dan pengolahan data yang dilakukan, dapat diambil kesimpulan

1. Berdasarkan hasil penelitian diketahui bahwa Tingkat Pengetahuan Ibu Hamil Trimester III Tentang perdarahan persalinan kala IV di Klinik Romana paling banyak dalam kategori berpengetahuan cukup yaitu 10 orang (50\%).

2. Berdasarkan hasil penelitian diketahui bahwa ibu hamil TM III yang memiliki penegtahuan cukup mengenai Perdarahan Persalinan Kala IV sebagian besar berumur 20-35 tahuan sebanyak 18 orang $(90 \%)$.

3. Berdasarkan hasil penelitian diketahui bahwa ibu hamil TM III yang memiliki penegtahuan cukup mengenai Perdarahan Persalinan Kala IV yaitu mayoritas multipara sebanyak 11 orang $(55 \%)$.

4. Berdasarkan hasil penelitian diketahui bahwa ibu hamil TM III yang memiliki penegtahuan cukup mengenai Perdarahan Persalinan Kala IV yaitu mayoritas berpendidikan SMA sebanyak 12 orang $(60 \%)$.

5. Berdasarkan hasil penelitian diketahui bahwa ibu hamil TM III yang memiliki penegtahuan cukup mengenai Perdarahan Persalinan Kala IV yaitu mayoritas yang tidak bekerja sebanyak 11orang (55\%). 


\section{Referensi}

Arieska, P. K. dan N. H. (2018). Pemilihan Teknik Sampling Berdasarkan Perhitungan Efesiensi Relatif. Jurnal Statistika, 6(2), 166-171.. https://jurnal.unimus.ac.id/index.php/statistik/article/view/4322/4001

BAPPENAS.2018.SEPAKAT.https://sepakat.bappenas.go.id/wiki/Kelompok_Usia

Fitriahadi, E., \& Utami, I. (2019). Buku Ajar asuhan Persalinan \& Managemen Nyeri Persalinan. 284.

Goyena, R. (2019). Resiko Perdarahan Pada Persalinan Kala IV. Journal Informasi, 53(9), 1689-1699. https://69ac0fa5-463b-40c0-84f3-934dbb043c0f

Kementrian Kesehatan Republik Indonesia. (2016). Profil Kesehatan Indonesia 2016. In Profil Kesehatan Provinsi Bali.http://www.depkes.go.id/resources/download/pusdatin/profilkesehatan-indonesia/Profil-Kesehatan-Indonesia-2016.pdf

Kemenkes RI. (2018). Profil Kesehatan Indonesia 2018 [Indonesia Health Profile 2018]. http://www.depkes.go.id/re (Rumini, 2009)sources/download/pusdatin/profil-kesehatanindonesia/Data-dan-Informasi Profil-Kesehatan-Indonesia-2018.pdf

Manuaba, I. B. G. (2018). Buku Ajar Patologi Obstetri. EGC. https://books.google.co.id/books?id=4Bi81bklxPQC\&dq=Ketuban+Pecah+Dini\&hl=id $\underline{\text { \&source}=g b s \_n a v l i n k s \_s}$

Masturoh, I., \& Anggita, N. (2018). Metodologi Penelitian. file:///D:/Documents/Downloads/Documents/Metodologi-Penelitian-Kesehatan_SC.pdf

Muslihatun, W. N., \& Retnaningsih, Y. (2019). Komplikasi Perdarahan Di Puskesmas Sedayu I Bantul Tahun 2018. http://eprints.poltekkesjogja.ac.id/2157/

Prawirohardjo, Sarwono.2014.Ilmu Kebidanan.Jakarta: PT Bina Pustaka

Ranita, S., Abdullah, T., \& Syafar, M. (2019). Factors Associated with Anxiety Third Trimester Pregnant Women in Dealing with Labor at Health Center of Kassi-Kassi Rappocini District, Makassar. 194-199. https://doi.org/10.36349/EASJNM.2019.v01i06.003

Sarwono. (2016). Ilmu Kebidanan jakarta : PT Bina Pustaka

Sumatera Utara, profil kesehatan. (2017). Profil Kesehatan Sumut 2017. Journal of Chemical Information and Modeling, 53(9), 1689-1699.

Wawan, A., \& M, D. (2019). Teori dan pengukuran pengetahuan, sikap, dan perilaku Manusia (III). Nuha Medika.

World Health Organization. (2017). Status of the health-related SDGs: Monitoring Health for the SDGs. Wealth $\quad$ Statistics, 29-35. 
JINTAN : Jurnal Ilmu Keperawatan

ISSN 2774-468X (Media Online)

Vol 1, No 2, Bulan Juli 2021

Hal 58-67

http://www.who.int/gho/publications/world_health_statistics/2017/EN_WHS2017_Part 2.pdf?ua $=1$

Yulia Sari, D, Program Studi Kebidanan, D \& Kedokteran Universitas Malahayati Bandar Lampung, F. (2017). Pengaruh Stimulasi Putting Payudara Terhadap Jumlah Pengeluaran Darah Pada Ibu Bersalin Kala IV Di Bpm Ari Saptuti, S.St Banyumas Kabupaten Pringsewu Tahun 2017. The Journal of Holistic Healthcare), 11(4), 204208.

Daftar pustaka, ditulis sesuai dengan aturan penulisan APA 6.0 edition, disusun berdasarkan abjad. 